\title{
Radio-laboratory findings in COVID-19 anosmia patients: a single-center experience
}

\author{
Tareq Muhammad Algarf ${ }^{1 *}$, Mahmoud Atef Youssef ${ }^{1}$, Mostafa Elshazly², Mohamed Said Ismail2, \\ Mohamed Kamal Hasswa ${ }^{2}$ and Mohamed Shaaban Mousa²
}

\begin{abstract}
Background: There is solid evidence that olfactory dysfunction (OD) can present in COVID-19 patients. Anosmia can be the only presentation or can be accompanied by other symptoms of COVID-19. Multiple cross-sectional studies have demonstrated that the incidence rate of olfactory dysfunction is high in COVID-19 patients with good prognosis. The aim of our study is to investigate the presence of $\mathrm{OD}$ with the radiologic and laboratory findings among COVID-19 positive patients.

Results: There was statistical significance in clinical severity between anosmia and non-anosmia group ( $P$ value 0.000) denoting that anosmia sign mostly occur in mild COVID. Also, there was significance in D dimer between two groups ( $P$ value 0.044 ) denoting that $D$ dimer could be a sign of clinical severity and it is usually not elevated in anosmia. All anosmia group had normal CT chest denoting that it is a mild form of COVID-19.

Conclusions: Olfactory dysfunction (OD) is an imminent sign of COVID-19 patient, which can be presented as a sole symptom or with other symptoms. As anosmia could be the sole clinical presentation of COVID-19 patients without any other significant signs and so otolaryngologists should be aware of this presentation in COVID-19 diagnosis.
\end{abstract}

Keywords: Covid 19, Anosmia, Olfactory dysfunction, Anosmia in covid, Anosmia in corona virus

\section{Background}

Coronavirus disease 2019 (COVID-19) is on-going pandemic started in Wuhan, China, in December 2019. It is caused by novel enveloped single-stranded ribonucleic acid (RNA) beta-coronavirus, which is known as the severe acute respiratory syndrome coronavirus 2 (SARS-CoV-2) [1].

To date, over 108.2 million COVID-19 cases and 2.3 million deaths have been reported to WHO till February 2021 [2].

COVID symptoms range from mild symptoms to severe illness. Symptoms may appear 2-14 days after

\footnotetext{
* Correspondence: tareqgarf@hotmail.com

1 Department of ENT, Faculty of Medicine, Cairo University, Giza, Egypt

Full list of author information is available at the end of the article
}

exposure to the virus. Typical symptoms include fever, cough, and shortness of breath [3].

A team at King's College, London, added loss of sense of smell to the COVID-19 symptom tracker. And it is a stronger predictor of coronavirus infection than fever [4].

In 17th April 2020, Center of Disease Control (CDC) set isolated anosmia as COVID-19 symptom followed by WHO in May 2020 [5].

In COVID-19 positive patients, 59\% reported losing their sense of smell or taste, compared with only $18 \%$ testing negative. So, anosmia is an early warning sign of infection, and patients should be self-isolated to reduce the spread of the disease [4].

Olfactory dysfunction often accompanied by dysgeusia in COVID-19 patients, suggesting a probable association between the two [6].

\section{Springer Open}

(c) The Author(s). 2021 Open Access This article is licensed under a Creative Commons Attribution 4.0 International License, which permits use, sharing, adaptation, distribution and reproduction in any medium or format, as long as you give appropriate credit to the original author(s) and the source, provide a link to the Creative Commons licence, and indicate if changes were made. The images or other third party material in this article are included in the article's Creative Commons licence, unless indicated otherwise in a credit line to the material. If material is not included in the article's Creative Commons licence and your intended use is not permitted by statutory regulation or exceeds the permitted use, you will need to obtain permission directly from the copyright holder. To view a copy of this licence, visit http://creativecommons.org/licenses/by/4.0/. 
A lot of studies correlate anosmia with the severity of COVID-19 illness. Mayo clinic systematic review suggested that OD may be associated with a milder course of COVID-19 infection [7].

Novelty of our study is to investigate the presence of OD with the radiologic and laboratory findings among COVID-19 positive patients.

\section{Methods}

Our study included total of 146 patients that were admitted to our institute. All patients were either mild or moderate COVID-19 that were admitted in inpatient wards.

Approval of the local ethical committee of the hospital was obtained to conduct the current study. Besides that, written informed consents were obtained from all participants clarifying the purpose of the study conforming Helsinki Declarations (1964).

In the absence of full objective smell assessment and nasopharyngoscope (contraindicated in the current situation), it is acceptable to depend on subjective selfassessment of olfactory dysfunction [8].

All included patients have been subjected to full medical history taking and were proven to be COVID-19 positive by PCR (nasopharyngeal swab). Prior to admission, all patients performed computed tomography (CT) of the chest and laboratory investigations in the form of CBC with differential count, ALT, AST, ferritin, CRP, D dimer, urea, and creatinine and detection of oxygen saturation by pulse oximetry. According to this initial assessment, severity of the condition could be determined.

Severity was classified into mild, moderate, or severe.

Mild type means mild symptoms in the absence of any radiological abnormalities in CT chest, moderate type includes fever and respiratory tract symptoms, and pneumonia is observed on imaging while severe type include any of the following criteria are met: respiratory distress as evidenced by respiratory rate $\geq 30$ breaths/ min, oxygen saturation $\leq 93 \%$ at rest, and arterial blood oxygen partial pressure/oxygen concentration $\leq 300$ $\mathrm{mmHg}$ with the lesions significantly progressing $>50 \%$ within 24-48 h on pulmonary imaging [9].

To be enrolled in the study, patients had to meet the following inclusion criteria: adults over 18 years of age, nasopharyngeal swab positive for COVID patients and acceptance for participation in the study.

On the other hand, the study exclusion criteria were uncooperative patients, patients on ventilators, psychiatric or neurological disorders, previous surgery, and radiation or trauma in nasal cavity.

A rapid office-based screening of smell disorder can be done, using a subjective olfaction score. The patient is asked to estimate his sense of smell on a 10-point scale bar with 0: anosmia, 10: normal smell and scores from 1 to 9 mean progressive increase in the degree of smell toward normal. As olfactory affection is a pertinent feature of COVID-19, ENT surgeons should pay attention to this particular disorder during patients' examination. The use of subjective olfaction score for rapid screening of patients may be beneficial to early diagnose the disease and prevent its spread [8].

We investigated the presence of OD with the radiologic and laboratory findings among COVID-19 positive patients.

\section{Statistical analysis}

Data was entered and statistically analyzed on the Statistical Package of Social Science Software program, version 25 (IBM SPSS Statistics for Windows, Version 25.0. Armonk, NY: IBM Corp.). Data was presented using range, mean, standard deviation, median and interquartile range for quantitative variables, and frequency and percentage for qualitative ones. Comparison between groups for qualitative variables was performed using Chi square or Fisher's exact tests while for quantitative variables the comparison was conducted using Mann-Whitney test. P values less than or equal to 0.05 were considered statistically significant.

\section{Results}

The current study included a total of 146 COVID-19 positive patients who were laboratory confirmed by RTPCR (nasopharyngeal swab), and were admitted to the hospital. All participants were Egyptians with mean age $38.34 \pm 11.72$ including 100 males (68.5\%) and 46 females $(31.5 \%)$ denoting male gender susceptibility to COVID-19 (Table 1).

Our patients were divided into two groups according to presence or absence of anosmia (Table 2).

In Table 1, patients were 146 and they were divided according to their symptoms into the following: 98 patients had no nasal symptoms and 30 patients had anosmia.

We found statistical significance in clinical severity between anosmia and non-anosmia group $(P$ value 0.000$)$ denoting that anosmia sign mostly occur in mild COVID (Fig. 1) (Table 2). Also, there was significance in D dimer between two groups ( $\mathrm{P}$ value 0.044 ) denoting that $\mathrm{D}$ dimer could be a sign of clinical severity and it is usually not elevated in anosmia.

\section{Discussion}

Olfactory neurons are the entry gate for neuro-invasion by coronavirus, which may be transferred to the central nervous system via a synapse-connected route. Still it is unclear whether olfactory sensory neurons are directly involved in the pathogenesis of smelling loss in COVID19. SARS-CoV-2 virus has a spiny protein $\mathrm{S} 1$, which makes the virion adhere to the cell membrane by 
Table 1 Demographic, laboratory, clinical, and radiologic assessment of patients

\begin{tabular}{|c|c|}
\hline & Description $(n=146)$ \\
\hline \multicolumn{2}{|l|}{ Age } \\
\hline Range & $22-68$ \\
\hline Mean \pm SD & $38.34 \pm 11.72$ \\
\hline Median (IQR) & $38(27-47)$ \\
\hline \multicolumn{2}{|l|}{ Sex } \\
\hline Male & $100(68.5)$ \\
\hline Female & $46(31.5)$ \\
\hline \multicolumn{2}{|l|}{ Occupation } \\
\hline Medical & $98(67.1)$ \\
\hline Non-medical & $48(32.9)$ \\
\hline \multicolumn{2}{|l|}{ Smoking } \\
\hline Smoker & $34(23.3)$ \\
\hline Non-smoker & $112(76.7)$ \\
\hline \multicolumn{2}{|l|}{ Baseline ferritin } \\
\hline Range & 7.3-1898 \\
\hline Mean \pm SD & $285.94 \pm 340.6$ \\
\hline Median (IQR) & $175.7(62-345)$ \\
\hline \multicolumn{2}{|l|}{ D dimer } \\
\hline Range & $0.1-4.43$ \\
\hline Mean \pm SD & $0.53 \pm 0.68$ \\
\hline Median (IQR) & $0.33(0.22-0.48)$ \\
\hline \multicolumn{2}{|l|}{ CRP } \\
\hline Range & $0.2-89$ \\
\hline Mean \pm SD & $12.08 \pm 16.66$ \\
\hline Median (IQR) & $5(2.2-15.9)$ \\
\hline \multicolumn{2}{|l|}{ Lymphopenia } \\
\hline Yes & $50(34.2)$ \\
\hline No & $96(65.8)$ \\
\hline \multicolumn{2}{|l|}{ Nasal } \\
\hline No & $116(79.45)$ \\
\hline Anosmia & $30(20.54)$ \\
\hline \multicolumn{2}{|l|}{ Severity } \\
\hline Mild & $84(57.5)$ \\
\hline Moderate & $62(42.5)$ \\
\hline
\end{tabular}

interacting with the host angiotensin-converting enzyme 2 (ACE2) receptor [6].

ACE2 is a functional receptor for SARS-CoV-2, and its expression and distribution in the nervous system suggest that SARSCoV-2 can cause neurological manifestations through direct or indirect pathways [6].

There is strong evidence that the nasal cavity is a crucial area susceptible to SARS-CoV-2 infection [10].

Viral loads in the patient's nasal cavity were higher than that present in the pharynx, both symptomatic
Table 2 Presence or absence of anosmia

\begin{tabular}{|c|c|c|c|}
\hline & \multicolumn{3}{|l|}{ Anosmia } \\
\hline & Yes $(n=30)$ & No $(n=116)$ & $P$ value \\
\hline \multicolumn{4}{|l|}{ Age } \\
\hline Range & $25-54$ & $22-68$ & \\
\hline Mean \pm SD & $36.13 \pm 9.26$ & $38.91 \pm 12.24$ & \\
\hline Median (IQR) & $31(28-46)$ & 38 (27-49) & 0.528 \\
\hline \multicolumn{4}{|l|}{ Sex } \\
\hline Male & $24(80)$ & $76(65.5)$ & 0.128 \\
\hline Female & $6(20)$ & $40(34.5)$ & \\
\hline \multicolumn{4}{|l|}{ Occupation } \\
\hline Medical & $24(80)$ & $74(63.8)$ & 0.092 \\
\hline Non-medical & $6(20)$ & $42(36.2)$ & \\
\hline \multicolumn{4}{|l|}{ Smoking } \\
\hline Smoker & $8(26.7)$ & $26(22.4)$ & 0.623 \\
\hline Non-smoker & $22(73.3)$ & 90 (77.6) & \\
\hline \multicolumn{4}{|l|}{ Baseline ferritin } \\
\hline Range & $22.4-814$ & 7.3-1898 & \\
\hline Mean \pm SD & $239.38 \pm 220.35$ & $297.98 \pm 365.13$ & \\
\hline Median (IQR) & 174 (82.9-287) & $178.3(55-352.4)$ & 0.969 \\
\hline \multicolumn{4}{|l|}{ D dimer } \\
\hline Range & $0.13-0.84$ & $0.1-4.43$ & \\
\hline Mean \pm SD & $0.32 \pm 0.17$ & $0.59 \pm 0.75$ & \\
\hline Median (IQR) & $0.27(0.2-0.33)$ & $0.35(0.23-0.5)$ & 0.044 \\
\hline \multicolumn{4}{|l|}{ CRP } \\
\hline Range & $0.2-36.7$ & $0.3-89$ & \\
\hline Mean \pm SD & $7.65 \pm 8.71$ & $13.23 \pm 18.01$ & \\
\hline Median (IQR) & $6.2(2.2-9.6)$ & $4.5(2.2-20)$ & 0.410 \\
\hline \multicolumn{4}{|l|}{ Lymphopenia } \\
\hline Yes & $12(40)$ & 38 (32.8) & 0.456 \\
\hline No & $18(60)$ & $78(67.2)$ & \\
\hline \multicolumn{4}{|l|}{ Severity } \\
\hline Mild & $26(86.7)$ & $58(50)$ & 0.000 \\
\hline Moderate & $4(13.3)$ & $58(50)$ & \\
\hline
\end{tabular}

individuals and asymptomatic ones, hinting the nasal cavity as nasal mucosa may be the initial site of SARSCoV-2 infection, in which the mode of transmission of SARS-CoV-2 is through infectious droplets [10].

However, COVID-19 case series reports showed a high rate of recovery of olfaction within 1-2 weeks after the onset of the dysfunction [11].

For these reasons, it is reasonable to put a hypothesis that the olfactory disorders (OD) are not related to, directly or indirectly, definitive viral damage to the neuronal cells. Conversely, the virus target may not be the neurons but other non-neuronal cells that express ACE2 receptors such as the olfactory epithelium 


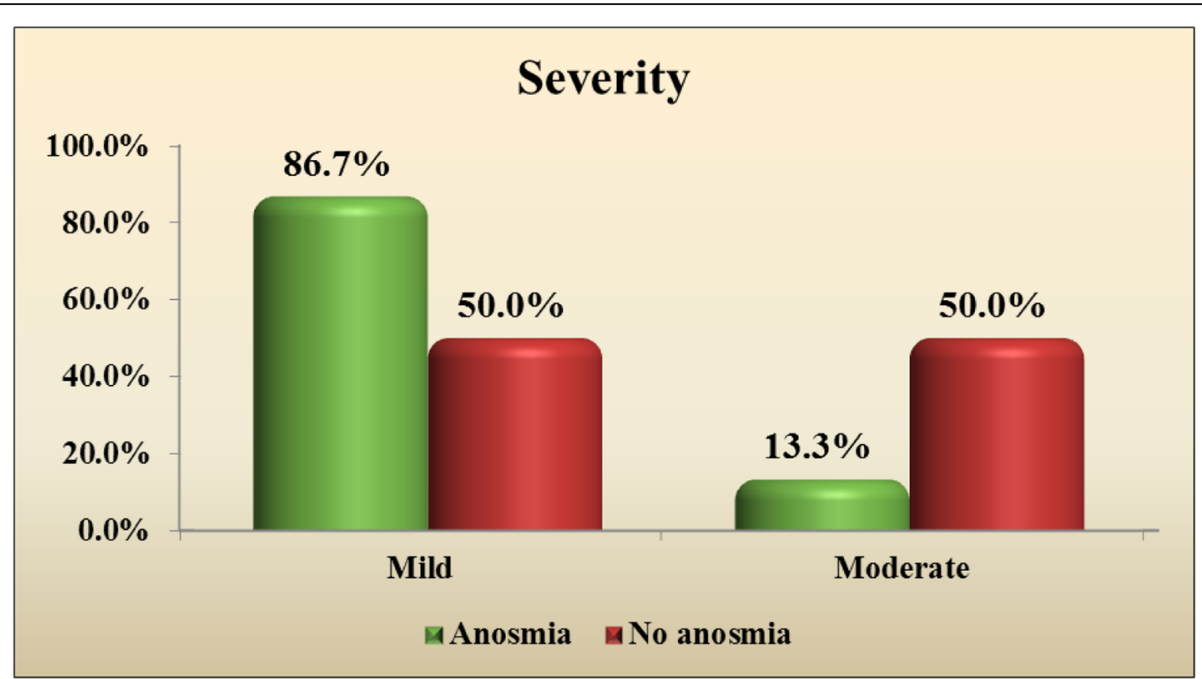

Fig. 1 Clinical severity in anosmia and non-anosmia group

sustentacular cells, microvillus cells, Bowman's gland cells, horizontal basal cells, and olfactory bulb pericytes [12].

Brann et al. supposed that the anosmia reported by COVID-19 patients is due to the infection of the supporting cells and vascular pericytes of the olfactory epithelium and bulb which, consequently, alters the function of the olfactory neurons [12].

Several cross-sectional studies about the prevalence rate of OD in COVID-19 patients have been released in many countries through non-contact methods such as online questionnaires and telephone interviews [13-15].

This study is novel as it correlates anosmia to radiolaboratory findings in COVID-19 patients.

Along with our study, incidence of OD in COVID-19 patients was around $25 \%$ in these studies [12-16].

The studies also showed that individuals with smell disorders tend to have a taste disorder, suggesting a probable association between the two symptoms [7, 12-16].

Contrary to our results, most studies have found that the incidence of smell disorders in COVID-19 patients is higher in females than males [7, 11, 14]. In Mayo clinic systematic review, no gender difference was observed [7].

In Hornuss D et al., mean age of anosmic patients was 56 years, total leukocytic count was 6.3 , lymphocyte was 0.8 , CRP was $60(\mathrm{mg} / \mathrm{L})$, and shortness of breath was in $65 \%$ of our patients study.

Our study mean age was 36 years; total leukocytic count was 6.6 while lymphocytic count was 0.2 . Moderate severity was found in $13 \%$ of patients.

Along with Mayo clinic systematic review [7], most of cases were mild in severity and CT chest was normal in majority of cases.
Majority of cases were of normal D dimer, leukocytic count, and lymphocytic count with no available studies to compare with.

\section{Limitations}

The subjective olfaction score is not a meticulous scoring. Psychophysical tests for evaluation of smell such as the Sniffing' Sticks test (Burghart; Wedel, Germany) and the University of Pennsylvania Smell Identification test (Sensonics Inc., Haddon Heights, NJ) are more reliable in the evaluation of olfaction, but they are not usually available during general health examination, besides being time consuming and costly.

The lack of consistent follow-up of our patients limits us from calculating the recovery time olfactory and gustatory functions, and, therefore, the percentage of permanent anosmia or ageusia.

\section{Conclusions}

OD is a prominent finding in COVID-19 patient, which can occur independently or with other symptoms, but its pathogenesis is not well understood. Otolaryngologists should be aware of anosmia as a presentation of COVID-19 infection to avoid delaying the diagnosis of COVID-19. As anosmia could be the sole clinical presentation of COVID-19 patients without any other significant signs, it pushes otolaryngologists not to delay COVID-19 diagnosis. To avoid cross-infection, the otolaryngologist may consider a remote olfactory evaluation for COVID-19 patient with OD.

\section{Abbreviations}

OD: Olfactory dysfunction; COVID-19: Coronavirus disease 2019; SARS-CoV2: Severe acute respiratory syndrome coronavirus 2; CDC: Center of Disease Control; PCR: Polymerase chain reaction; ACE2: Angiotensin-converting enzyme 2 


\section{Acknowledgements}

Not applicable

\section{Authors' contributions}

TM organized patient's data and wrote the manuscript. MS organized the patient's sheets and collected data. MA organized and tabulated results. MI and MK collected references of the study. ME revised the manuscript and references. The authors read and approved the final manuscript.

\section{Funding}

Self-funded

\section{Availability of data and materials}

The data of the study are available at the corresponding author upon request.

\section{Declarations}

Ethics approval and consent to participate

This study was approved by the Ethics Committee of Kasr Alaini Hospital of Cairo University with approval number [N-33-2020]. Patients included in the study provided written consent.

\section{Consent for publication}

Not applicable.

\section{Competing interests}

The authors declare that they have no competing interests.

\section{Author details}

'Department of ENT, Faculty of Medicine, Cairo University, Giza, Egypt. ${ }^{2}$ Department of Pulmonary Medicine, Faculty of Medicine, Cairo University, Giza, Egypt.

Received: 24 October 2020 Accepted: 29 April 2021

Published online: 29 July 2021

\section{References}

1. Guan WJ, Ni ZY, Hu Y et al (2019) Clinical characteristics of coronavirus disease 2019 in China. N Engl J Med 382:1708-1720. https://doi.org/10.1 056/NEJMoa2002032

2. (2021) Coronavirus disease 2019 (COVID-19). Situation reports . https://www. who.int/publications/m/item/weekly-epidemiological-update\%2D\%2D-16february-2021. Accessed 21 Feb 2021

3. CDC. Coronavirus disease 2019 (COVID-19). (2020). https://www.cdc.gov/ coronavirus/2019-ncov/symptoms testing/symptoms.html. Accessed 7 Jul 2020

4. ENT-UK. Loss of sense of smell as marker of COVID-19 infection 2020: https://www.entuk.org/sites/default/files/files/Loss\%20of\%20sense\%20of\%2 Osmell\%20as\%2.

5. American Academy of Otolaryngology. Head and neck surgery .AAO-HNS: Anosmia, Hyposmia, and dysgeusia symptoms of coronavirus disease 2020: https://www.entnet.org/content/aao-hns-anosmia-hyposmia-and-dysgeusiasymptomscoronavirus-disease.

6. Giacomelli A, Pezzati L, Conti F, Bernacchia D, Siano M (2020) Oreni L (2020): Self-reported olfactory and taste disorders in SARS-CoV-2 patients: a crosssectional study. Clin Infect Dis. https://doi.org/10.1093/cid/ciaa330

7. Akosua Adom Agyeman, Ken L. Chin, MClinPharm, Cornelia B. Landersdorfer, Danny Liew, and Richard Ofori-Asenso; Smell and taste dysfunction in patients with COVID-19: a systematic review and metaanalysis, Mayo Clin Proc. August;95(8):1621-1631, doi: https://doi.org/10.101 6/j.mayocp.2020.05.030

8. Abdel-Aziz M. (2020); Smell disorder could warn head and neck surgeons for diagnosis of COVID-19. J Craniofac Surg. doi: https://doi.org/10.1097/SCS. 0000000000006844

9. Jin A, Yan B, Hua W, Feng D, Xu B, Liang L (2020) Clinical characteristics of patients diagnosed with COVID-19 in Beijing. Biosafety Health 2:104-111

10. Li Y-C, Bai W-Z, Hashikawa T (2020) The neuroinvasive potential of SARSCoV2 may play a role in the respiratory failure of COVID-19 patients. J Med Virol. 92(6):552-555. https://doi.org/10.1002/jmv.25728
11. Mao L, Wang M, Chen $S$ et al Neurological manifestations of hospitalized patients with COVID-19 in Wuhan, China: a retrospective case series study. MedRXiv. Doi. https://doi.org/10.1101/2020.02.22.20026500

12. Brann DH, Tsukahara T, Weinreb C et al (2020) Non-neuronal expression of SARS-CoV-2 entry genes in the olfactory system suggests mechanisms underlying COVID-19-associated anosmia. BioRxiv. https://doi.org/10.1101/2 020.03.25.009084

13. Giacomelli A, Pezzati L, Conti F, Bernacchia D, Siano M, Oreni L (2020) Self-reported olfactory and taste disorders in SARS-CoV-2 patients: a cross-sectional study. Clin Infect Dis 71(15):889-890. https://doi.org/10.1 093/cid/ciaa330

14. Bagheri SHR, Asghari AM, Farhadi M, Shamshiri AR, Kabir A, Kamrava SK (2020) Coincidence of COVID-19 epidemic and olfactory dysfunction outbreak. medRxiv. https://doi.org/10.1101/2020.03.23.20041889

15. Yan CH, Faraji F, Prajapati DP, Boone CE, DeConde AS (2020) Association of chemosensory dysfunction and COVID-19 in patients presenting with influenza-like symptoms. Int Forum Allergy Rhinol

16. Menni C, Valdes A, Freydin MB, Ganesh S, El-Sayed MJ, Visconti A (2020) 13s: Loss of smell and taste in combination with other symptoms is a strong predictor of COVID-19 infection. medRxiv. Nat Med. 26:1037-1040. https:// doi.org/10.1101/2020.04.05.20048421

\section{Publisher's Note}

Springer Nature remains neutral with regard to jurisdictional claims in published maps and institutional affiliations.

\section{Submit your manuscript to a SpringerOpen ${ }^{\circ}$ journal and benefit from:}

- Convenient online submission

- Rigorous peer review

- Open access: articles freely available online

- High visibility within the field

- Retaining the copyright to your article

Submit your next manuscript at $\boldsymbol{\nabla}$ springeropen.com 